\title{
AQUAPONICS: A POTENTIAL OPTION FOR URBAN FOOD SUPPLEMENT IN KATHMANDU VALLEY
}

\author{
Udhab Raj Khadka ${ }^{1 *}$, Sanu Maiya Maharjan² \\ ${ }^{1}$ Associate Professor, Central Department of Environmental Science, Kirtipur, TU \\ ${ }^{2}$ Associated with the Youth Alliance for Environment, Kathmandu \\ *Corresponding author
}

\begin{abstract}
Growing urbanization in Kathmandu Valley has reduced the agriculture land and is anticipated further reduction coming days leading to agricultural vulnerability. The increasing built-up areas, however, might be opportunity for alternative methods of agriculture production like aquaponics which incorporates both aquaculture and hydroponics in a single unit. This system helps to produce food (fish and vegetables), especially in the areas where the availability of cultivable land and water is scarce. This study was carried out to demonstrate the feasibility of aquaponics in Kathmandu Valley. For the experiment, two media filled aquaponic systems (MFS) covering one square meter area were set-up using hogplum (Choerospondias axillaries) seeds $\left(\mathrm{B}_{\mathrm{h}}\right)$ and gravels $\left(\mathrm{B}_{\mathrm{g}}\right)$ as growing media in hydroponic and systems were named as AS-1 and AS-2, respectively. In both $\mathrm{B}_{\mathrm{h}}$ and $\mathrm{B}_{\mathrm{g}}$, 11 seedlings of Indian spinach having $5 \mathrm{~g}$ total weight were transplanted in grow bed containing hog-plum, and 15 catfish (Clariasbatrachus) having 45 $\mathrm{g}$ weight were stocked in Tank-1 (T-1) of AS-1. Likewise, in AS-2 system, $5 \mathrm{~g}$ spinach were transplanted in grow-bed containing gravel, and 34 carp (Cyprinus sp.) fish having $34 \mathrm{~g}$ weight were stocked in Tank-2 (T-2) of AS-2. After 40 days, $550 \mathrm{~g}$ spinach was produced from the system containing hog-plum seeds as growbed and $1060 \mathrm{~g}$ spinach from the system containing gravel as grow-bed. Likewise, $45 \mathrm{~g}$ catfish reached $550 \mathrm{~g}$ in 90 days in Tank-1 (T-1) and $34 \mathrm{~g}$ carp reached $109 \mathrm{~g}$ in Tank-2 (T2). All the growth performances like specific growth rate (SGR), average daily growth (ADG), daily growth index (DGI), percent weight gain (\%WG) of Indian spinach in grow-bed containing gravel $\left(\mathrm{B}_{\mathrm{g}}\right)$ were found higher in comparison to the grow-bed containing hog-plum seed $\left(\mathrm{B}_{\mathrm{h}}\right)$. The survival rate of catfish and carp was found to be $86.7 \%$ and $90.6 \%$, respectively. The growth performance of Indian spinach was significantly different $(p<0.05)$ in the two growing media.
\end{abstract}


This result shows that aquaponics has potential to produce both fish and spinach simultaneously at the same unit using small space in city like Kathmandu Valley. Further detailed study is required for comparative study of fish and evaluating cost and benefit, and commercial potentiality.

Keywords: aquaculture - hog-plum seeds - hydroponics - Indian spinach - media filled aquaponic system.

\section{INTRODUCTION}

Urbanization has become a universal and has accelerated worldwide during the last century accounting 50\% (3.3 billion) of the world human population living in urban areas (Thapa \& Murayama 2009). It is expected that the world's population will reach around 9.6 billion by 2050 with more than 75\% living in urban areas (Goddek et al., 2015). Rapid urbanization is an ongoing process and is the most dominant phenomenon in all developing countries (Thapa \& Murayama 2009) and Nepal is no exception to this phenomena. Kathmandu Valley is the major urban area of Nepal. Over the period of 22 years (1990-2012 AD), built-up area in the valley has increased from $38 \mathrm{~km}^{2}$ to $119 \mathrm{~km}^{2}$ with a staggering $211 \%$ increase and decrease in agricultural land from $421 \mathrm{~km}^{2}$ to $342 \mathrm{~km}^{2}$ accounting $19 \%$, causing drastic change in urban morphology. Similarly, proportional transition of other land uses was also increasingly changed to urban/built-up areas. Till 2000, the agricultural land in Kathmandu Valley used to cover $53.83 \%$ of the total area; however in 2012 the agriculture land-coverage accounted only 47.39\% (Thapa \& Murayama 2009). Growing human population as well as proportionate increase in the requirement of food is one of the challenges in Nepal. The decreased agricultural land and at the same time increasing built-up area is affecting food production in Kathmandu Valley, which leads valley dwellers towards vulnerable situation. Therefore, it is essential to explore alternative food production using built-up areas and non-cultivable lands to meet the increased demand of growing population. In this context, aquaponics may be one of the possible options for supplementary food production.

Aquaponics is a food production system which integrates aquaculture (fish farming) and hydroponics (growing crop plants in soilless condition), where both the agricultural practices mutually benefits from each other in a single production unit. It is completely sustainable agriculture or food production system (Abdulkhader, 2014, Bethe 2014; Consulting, 2013; Goodman, 2005; Roy et al., 2012; Tyson et al., 2011) as 
it uses renewable resources and on-farm resources efficiently. The key of aquaponics system is the waste products of one biological system serves as nutrients to the other biological system and water is re-used through biological filtration (Bethe, 2014). In this system, fish grown in a tank excretes waste materials containing ammonia, through urine, their gills and from remaining feeds into the surrounding water (Fig. 1). Over time, these waste materials which are toxic to fish accumulate (Bethe 2014; Nelson, 2008) and affect adversely the growth of fish (Abdulkhader 2014, Bethe 2014, Racoky et al. 2006, Sace \& Fitzsimmons 2013, Tyson et al. 2011). However, the same wastes can be used as an organic fertilizer for plants. The water from fish tank pumped to the hydroponic, where plants use nitrate from water for their metabolic activities and then the filtered water goes back to the fish tank.

In aquaponics, the ammonia containing waste generated by fish is converted into fertilizer for plants by nitrification process. Nitrite and nitrate is much less toxic to fish than ammonia, but for the good health of the fish they must be kept at low level (Blidariu et al. 2011). This is an energy efficient system which prevents discharge of waste materials into the environment, provides organic fertilizers to plants, reuses the wastewater through bio-filtration and ensures higher production of food per unit area through multiple cropping (Lennard 2010). This system can be builtup in all environmental conditions, in various structures and sizes. All kind of green leafy vegetables including herbs and edible as well as decorative (non-edible) fish can be grown in this system (Abdulkhader 2014, Racoky et al. 2006). Therefore, in the present context of growing urbanization and reducing agricultural land in the Kathmandu Valley, the present study was carried out with the aim of examining the potential of food production by using aquaponics in Kathmandu Valley.

\section{MATERIALS AND METHODS}

\section{Experimental site}

In the present study, among the three most widely used aquaponic systems, Media Filled System (MFS) was selected for the experiment. The system was installed in Janachahana Marga, Kapurdhara, Kathmandu, Nepal. 


\section{Materials}

Different materials such as plastic barrels of 200 L capacity (90 $\mathrm{cm} \times 60 \mathrm{~cm} \times 60 \mathrm{~cm}$ ) to make fish tanks and grow-beds, water pumps (RS 2680F, 220V to $240 \mathrm{~V} / 50 \mathrm{~Hz}, 30 \mathrm{w}, 2100 \mathrm{~L} / \mathrm{h}$ at $1.6 \mathrm{~m}$ head), aeration pumps (Daivo air Pump, NS-8200 SW, 220v to 240v/50 Hz) with $26 \mathrm{~cm}$ long air stone, Polypropylene Random (PPR) pipes and fittings, iron stands, growing medias: hog-plum (Choerospondias axillaris, Lapsi in Nepali) seeds and small gravels, Indian spinach (Basella alba) as plant species and catfish (Clarias batrachus; Magur Machha in Nepali, Family: Claridae) and carp (Cyprinus sp., Family: Cyprinidae) as fish species were used for the experimental set-up.

\section{Methods}

\section{Experimental set up}

Two experimental sets of Media Filled System (Photo. 1) were installed to determine the yield and growth of Indian spinach and fish. Each system comprised of a fish tank $\left(0.2 \mathrm{~m}^{3}\right)$, a hydroponic tank $\left(0.5 \mathrm{~m}^{2}\right)$, a submersible pump with pipe arrangements, air pump connected with air stones and ball valves to regulate the water flow (Figure 1, Photo 1).

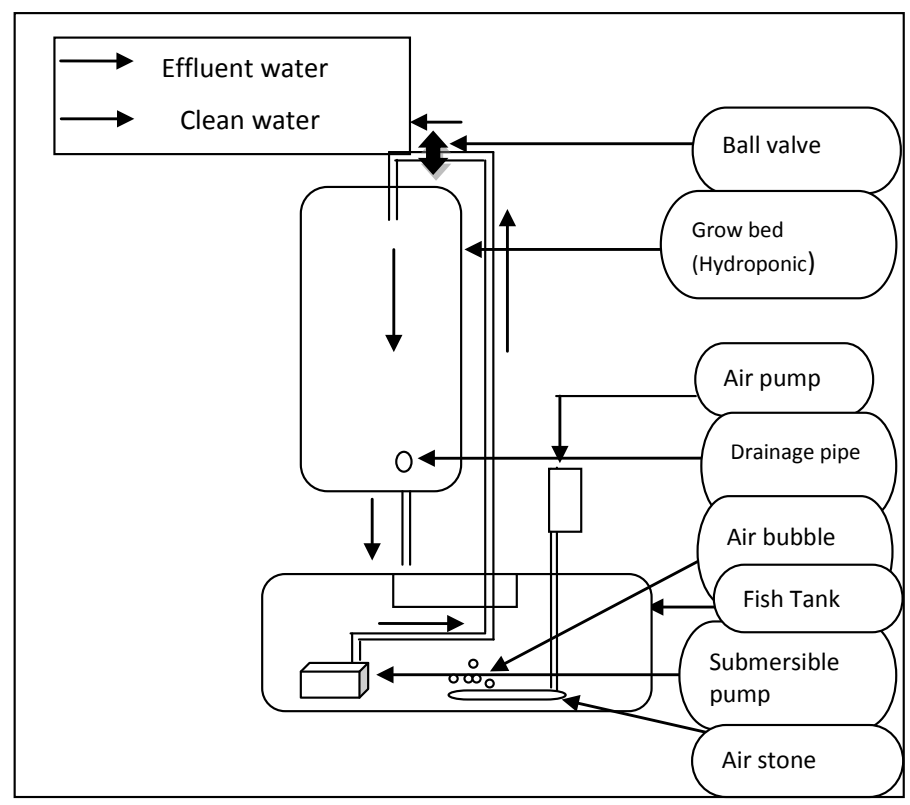

Figure 1: Schematic of aquaponic system (Modified from Hussain et al. 2014) 
The system filled with hug-plum seeds was named as AS-1and system filled with small gravels was named as AS-2. The fish tank of AS-1 system was named as T-1and that of AS-2 system as T-2. Similarly, the grow-beds were indicated as $\mathrm{B}_{\mathrm{h}}$ for $\mathrm{AS}-1$ and $\mathrm{B}_{\mathrm{g}}$ for $\mathrm{AS}-2$. In each system $1 / 2$ inch $(1.27 \mathrm{~cm})$ PPR pipes were connected from the fish tank to the hydroponic tanks to let the water flow. Constant water flow was regulated by $1 / 2$ inch diameter ball valves and $3 / 4$ inch $(1.905 \mathrm{~cm})$ diameter standpipe (drainage pipe) in the grow-beds. The standpipe was covered by 2.5 inch $(6.35 \mathrm{~cm})$ bell siphon.

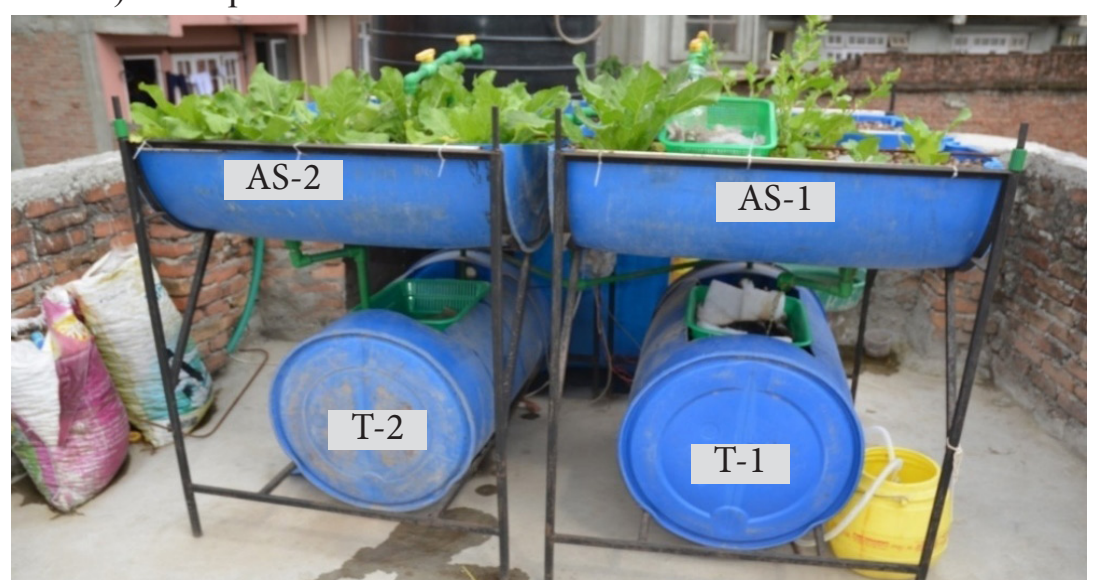

Photo 1: Experimental setting of media filled aquaponics system

\section{Fish stocking and feeding}

Fifteen catfish and 34 carp were stocked in the tank T-1 of AS-1and $\mathrm{T}_{2}$ of AS-2, respectively. Before releasing to the tank, fish were acclimatized in the local environment for 15 minutes. Commercial floating pellets having size 1-3 mm with nutrient value of $42 \%$ crude protein, $3 \%$ crude fat, $6 \%$ crude fiber, $10 \%$ moisture were used to feed the fish. The fish was fed once a day, in between 10:00 am and 12:00 pm, at the rate of 3\% of their body weight.

\section{Germination and transplantation of spinach}

The seeds were sown in plastic bottle (cut, filled with saw dust). After, 20 days of germination, 11 seedlings were plucked-up, washed and transplanted carefully in each grow-bed approximately at $20 \mathrm{~cm}$ interval. 


\section{Harvesting spinach and weighing the fish}

Spinach was harvested after 40 days of transplantation into the grow-beds and on the same day of weigh of fish was also taken. Whole plant of spinach was taken out from the grow-beds carefully and then recorded the weight, height, leaf length and root length of plants. The weight of catfish was taken after 90 days of releasing fingerlings in $T_{1}$ tank and weight of carp was taken after 24 days of releasing fingerlings in $T_{2}$ tank. Both catfish and carp were taken out using small hand net from the respective tanks, then counted and weighed. Catfish was weighed individually, but carp weighed in a bulk. After completion of weighing, fish were immediately released back to the respective tanks.

\section{Water quality monitoring}

During the experimental period, water quality parameter such as $\mathrm{pH}$, temperature, ammonia, ammonium ion, nitrite and nitrate were monitored using water quality test kits. The ammonia and ammonium ion was examined by the API $\mathrm{NH}_{3} / \mathrm{NH}_{4}^{+}$Aquarium Pharmaceuticals test kit (Mars Fishcare, North America Inc). Nitrate was examined by the Sera nitrate test kit (Hersteller: sera GmbH, D 52518 Heinsberg, Germany).

\section{Growth performances}

Growth performance of spinach and fish were calculated using the following formulae;

Mean weight gain $(\mathrm{MWG})=\mathrm{W}_{\mathrm{t}}-\mathrm{W}_{\mathrm{i}}$

Percent weight gain $(\% \mathrm{WG})=\left[\left(\mathrm{W}_{\mathrm{tm}}-\mathrm{W}_{\mathrm{im}}\right) / \mathrm{W}_{\mathrm{im}}\right] * 100$

Specific growth rate $(\mathrm{SGR}, \% /$ day $)=\left[\left(\log _{\mathrm{e}} \mathrm{W}_{\mathrm{tm}}-\log _{\mathrm{e}} \mathrm{W}_{\mathrm{im}}\right) / \mathrm{T}\right] \times 100$

Survival rate $(\% \mathrm{SR})=\left(\mathrm{H}_{\mathrm{n}} / \mathrm{S}_{\mathrm{n}}\right) * 100$

Mean length gain $(\mathrm{cm})=\mathrm{L}_{\mathrm{tm}}-\mathrm{L}_{\text {im }}(\mathrm{cm})$ (Bethe, 2014)

Average daily growth $(\mathrm{ADG} \%)=100[\mathrm{Wt}-\mathrm{Wi} / \mathrm{Wi} \times \mathrm{T}]$

Daily growth index $\left(\right.$ DGI \%) $=100 \mathrm{x}\left[(\mathrm{Wt})^{1 / 3}-(\mathrm{Wi})^{1 / 3}\right] / \mathrm{T}$ .......(Bekcan et al., 2006)

Where,

$\mathrm{W}=$ weight

$\mathrm{Wi}=$ initial weight of fish

$\mathrm{Wt}=$ final weight of fish

$\mathrm{W}_{\mathrm{tm}}=$ mean final weight

$$
\begin{array}{ll}
\mathrm{W}_{\mathrm{im}}=\text { mean initial weight } & \mathrm{L}_{\mathrm{im}}=\text { mean initial length } \\
\mathrm{T}=\text { duration } & \mathrm{H}_{\mathrm{n}}=\text { number of fish harvest and } \\
\mathrm{L}_{\mathrm{tm}}=\text { mean final length } & \mathrm{S}_{\mathrm{n}}=\text { number of fish stocked }
\end{array}
$$




\section{Data analysis and presentation}

The experimental data were compiled and collated for different media in "Microsoft Excel 2007". The statistical analysis for determining the significant difference in mean weight of spinach in two systems was carried out using the t-test in R software (Version 3.1.3).

\section{RESULTS AND DISCUSSION}

\section{Production of Indian spinach and fish}

With respect to spinach, in AS-1 system containing hog-plum seeds $\left(\mathrm{B}_{\mathrm{h}}\right.$ ) as grow-bed, $5 \mathrm{~g}$ initial total weight increased to $550 \mathrm{~g}$ (with mean weight $47.7 \pm 21.32 \mathrm{~g}$ ) in 40 days. In AS-2 system containing gravel $\left(\mathrm{B}_{\mathrm{g}}\right)$ as grow-bed, $5 \mathrm{~g}$ initial total weight increased to $1060 \mathrm{~g}$ (with mean weight $96.4 \pm 15.65 \mathrm{~g}$ (Table 1). The final mean height of spinach was recorded to be $41.0 \pm 3.65 \mathrm{~cm}$ in $B_{h}$ and $49.73 \pm 2.92 \mathrm{~cm}$ in $B_{g}$ (Table 1). Similarly, final mean leaf length was recorded to be $19.6 \pm 2.55 \mathrm{~cm}$ in $\mathrm{B}_{\mathrm{h}}$ and $28.5 \pm 3.05$ $\mathrm{cm}$ in $\mathrm{B}_{\mathrm{g}}$ and final mean root length was found to be $21.3 \pm 1.76 \mathrm{~cm}$ in $\mathrm{B}_{\mathrm{h}}$ and $21.27 \pm 1.89 \mathrm{~cm}$ in $\mathrm{B}_{\mathrm{g}}$ (Table 1). The mean leaf length gain in $\mathrm{Bh}$ was $16.2 \mathrm{~cm}$, in $\mathrm{Bg}$ was $24.4 \mathrm{~cm}$. Likewise, mean root length gain in $\mathrm{B}_{\mathrm{h}}$ and $\mathrm{B}_{\mathrm{g}}$ were 14.0 and $17.3 \mathrm{~cm}$, respectively. The mean height gain of spinach was $42.3 \mathrm{~cm}$ in $\mathrm{B}_{\mathrm{g}}$ and $29.6 \mathrm{~cm}$ in $\mathrm{B}_{\mathrm{h}}$ (Table 2; Fig. 2). The SGR, ADG and DGI were found to be relatively high in Bg (Table 2; Fig 2). Hossain et al. (2014) has reported fresh weight gain of individual plant to be $72.75 \mathrm{~g}$, leaf (shoot) length to be $29.33 \mathrm{~cm}$ and root $16.00 \mathrm{~cm}$ after 60 days of sowing spinach in pot using soil with Biogas Plant Residue (BPR). The present study shows that mean weight of spinach is higher $(96.4 \mathrm{~g})$ in grow-bed containing gravel and lower in grow-bed containing hog-plum seeds (Table 1). However, leaf and root length is lower in both systems in compared to Hossain et al. (2014).

The t-test shows significant differences $(p<0.05)$ between the growth performance of Indian spinach in grow-beds using hog-plum seeds $\left(\mathrm{B}_{\mathrm{h}}\right)$ in AS-1 system and small gravel $\left(\mathrm{B}_{\mathrm{g}}\right)$ in AS-2 system. The result shows that the production of spinach is better in AS-2 than AS-1. Thus, for the growth of Indian spinach gravel is an effective bed material than hog-plum seeds in media filled aquaponics. 
Table 1: Growth of Indian spinach and fish in Aquaponics System

\begin{tabular}{lcccc}
\hline \multicolumn{1}{c}{$\begin{array}{c}\text { Growth Performances } \\
\text { (Units) }\end{array}$} & \multicolumn{2}{c}{ Spinach } & \multicolumn{2}{c}{ Fish } \\
\cline { 2 - 5 } & $\begin{array}{c}\mathbf{B}_{\mathbf{h}} \text { (AS-1) } \\
\mathbf{n}=\mathbf{1 5}\end{array}$ & $\begin{array}{c}\mathbf{B}_{\mathbf{g}} \text { (AS-2) } \\
\mathbf{n = 1 5}\end{array}$ & $\begin{array}{c}\text { T-1 (AS-1) } \\
\mathbf{n = 1 5}\end{array}$ & $\begin{array}{c}\text { T-2 (AS-2) } \\
\mathbf{n = 3 4}\end{array}$ \\
\hline Initial Total Weight (g) & 5 & 5 & 45 & 34 \\
Initial Mean Weight (g) & $0.45 \pm 0.62$ & $0.45 \pm 0.62$ & $3 \pm 1.10$ & $1.06 \pm 1.18$ \\
Final Total Weight (g) & 550 & 1060 & 550 & 109 \\
Final Mean Weight (g) & $47.7 \pm 21.32$ & $96.4 \pm 15.65$ & $36.7 \pm 7.4$ & $3.21 \pm 0.06$ \\
Initial Mean Height (cm) & $11.4 \pm 1.03$ & $7.38 \pm 2.92$ & & \\
Final Mean Height (cm) & $41.0 \pm 3.65$ & $49.73 \pm 2.92$ & & \\
Initial Mean Leaf Length (cm) & $3.5 \pm 0.14$ & $4.1 \pm 0.16$ & & \\
Final Mean Leaf Length (cm) & $19.6 \pm 2.55$ & $28.5 \pm 3.05$ & & \\
Initial Mean Root Length (cm) & $7.3 \pm 0.99$ & $3.9 \pm 0.43$ & & \\
Final Mean Root Length (cm) & $21.3 \pm 1.76$ & $21.27 \pm 1.89$ & & \\
\hline
\end{tabular}

$B_{g}=$ Growbed filled with gravels, $B_{h}=$ Growbed filled with hog-plum seeds $T-1=$ Fish tank rearing catfish,

T-2 = Fish tank rearing carp, AS-1= Aquaponics System-1, AS-2= Aquaponics System-2

Similarly, in case of fish, $45 \mathrm{~g}$ catfish grew to $550 \mathrm{~g}$ (with mean weight $68.8 \pm 7.28 \mathrm{~g}$ ) from Tank-1 (T-1) of AS-1 system and $34 \mathrm{~g}$ carp grew to $109 \mathrm{~g}$ (with mean weight $3.21 \pm 0.86 \mathrm{~g}$ ) from Tank- 2 (T-2) of AS-2 system (Table 1) in $0.2 \mathrm{~m}^{3}$ volumes. Catfish gained $505 \mathrm{~g}$ weight (with mean $36.7 \pm 7.40 \mathrm{~g}$ ) in 90 days and the carp gained $75 \mathrm{~g}$ (with mean $3.21 \pm 0.06 \mathrm{~g}$ ) in 24 days (Table 2). The specific growth rate (SGR) of catfish in 90 days was found to be $2.78 \%$ day $^{-1}$ in T-1 and that of carp in T-2 was found to be $4.85 \%$ day $^{-1}$ in 24 days (Table 2, Fig. 3). Himadri and Debajyoti (2012) have reported that in 90 days, catfish gained mean final weight of 21.79 g with SGR $1.83 \%$ day $^{-1}$ in a cemented tank filled with agricultural soil at bottom. Likewise, Dehaghani et al. (2015) reported that carp gained mean final weight $1.26 \pm 0.28 \mathrm{~g}$ with SGR $0.82 \pm 1.29 \%$ day $^{-1}$ in tank in 30 days. This shows that mean final weight and SGR $\left(\%\right.$ day $\left.^{-1}\right)$ of both fish is higher in the present study compared to Dehaghani et al. (2015). According to Bekcan et al. (2006), the SGR value depends on the protein levels of fish feed. The feed containing 40\% protein increases the SGR, but decreases beyond that level. In the present study, fish were fed with feed containing $42 \%$ crude protein, which is slightly higher than suggested by Bekcan et 
al. (2006). The mortality of fish was observed at the starting period, this may be due to lack of immediate tolerance capacity of fish to adjust the environment of the water in the tank.

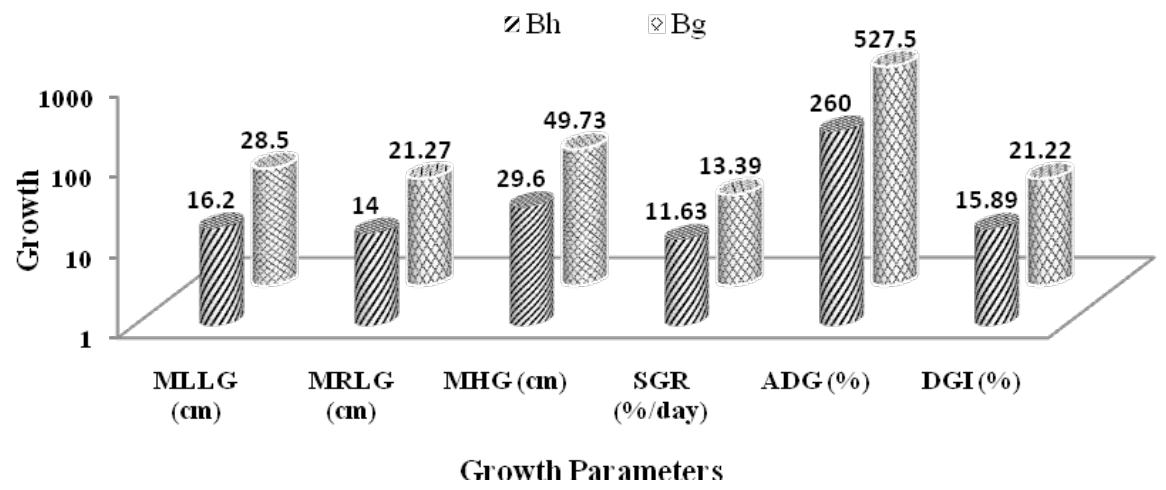

$M M L G=$ Mean Leaf Length Gain, MRLG = Mean Root Length Gain, MHG = Mean Height Gain, SGR = Specific Growth Rate, ADG = Average Daily Growth, $D G I=$ Daily Growth Index

Figure 2: Growth performance of Indian Spinach

Table 2: Growth performance of Indian spinach and fish in Aquaponics System

\begin{tabular}{|c|c|c|c|c|}
\hline \multirow{2}{*}{$\begin{array}{c}\text { Growth Performances } \\
\text { (Units) }\end{array}$} & \multicolumn{2}{|c|}{ Spinach } & \multicolumn{2}{|c|}{ Fish } \\
\hline & $\begin{array}{c}\mathrm{B}_{\mathrm{h}}\left(\mathrm{AS}_{1}\right) \\
\mathrm{n}=15\end{array}$ & $\begin{array}{c}\mathrm{B}_{\mathrm{g}}\left(\mathrm{AS}_{2}\right) \\
\mathrm{n}=15\end{array}$ & $\begin{array}{c}T_{1}\left(A S_{1}\right) \\
n=15\end{array}$ & $\begin{array}{c}\mathrm{T}_{2}\left(\mathrm{AS}_{2}\right) \\
\mathrm{n}=\mathbf{3 4}\end{array}$ \\
\hline Weight Gain (g) & 545 & 1055 & 505 & 75 \\
\hline Mean Weight Gain (g) & 47.27 & 95.91 & 65.8 & 2.1 \\
\hline Mean Leaf Length Gain (cm) & 16.2 & 24.4 & --- & --- \\
\hline Mean Root Length Gain (cm) & 14 & 17.3 & --- & --- \\
\hline Mean Height Gain $(\mathrm{cm})$ & 29.6 & 42.3 & --- & --- \\
\hline Specific Growth Rate $\left(\%\right.$ day $\left.^{-1}\right)$ & 11.63 & 13.39 & 2.78 & 4.85 \\
\hline Average Daily Growth (\%) & 260 & 527.5 & 12 & 9.2 \\
\hline Daily Growth Index (\%) & 15.89 & 21.22 & 5.15 & 6.4 \\
\hline Survival Rate $(\%)$ & --- & --- & 86.67 & 90.63 \\
\hline
\end{tabular}

$B_{g}=$ Grow-bed filled with gravels, $B_{h}=$ Grow-bed filled with hog-plum seeds, $T-1=$ Fish tank rearing catfish,

T-2 = Fish tank rearing carp, AS-1= Aquaponics System 1, AS-2= Aquaponics System 2 


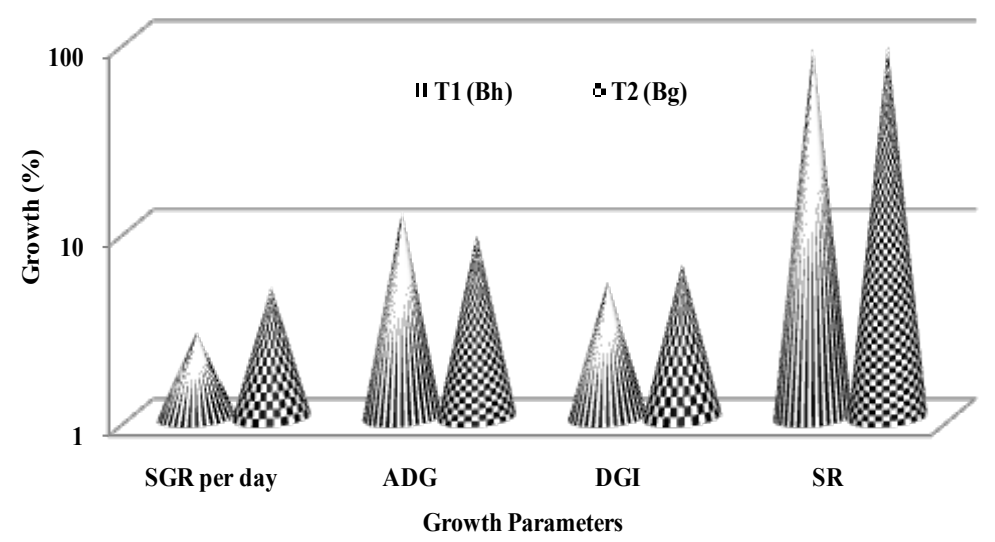

$S G R=$ Specific Growth Rate, ADG = Average Growth Rate, DGI = Daily Growth Index, SR = Survival Rate

Figure 3 Growth performances of fish

\section{Potential of aquaponics in Kathmandu Valley}

The land-use of Kathmandu Valley has drastically changed over the last 45 years (1967-2012). During this period, most of the productive agricultural lands have been converted to urban built-up areas, particularly in the valley floor and nearby hills. A large share (26\%) of agricultural land has been changed to built-up residential area in different periods (KVDA, 2015). The decreasing agricultural land is leading towards low food production in the valley. This situation increases the import of food from outside the valley to fulfill the demand of increasing population. Nepal imported foodstuffs worth US \$621 million and exported agricultural products worth less than half, US \$248 million. During 2010/2011, out of total, $8.29 \%$ of food was produced in the valley itself, $63.17 \%$ was imported from other areas in Nepal, 26.3\% from India and 2.24\% from China (Dixit et al., 2014). The foods imported by travelling long distance to the valley not only deprived the people from consuming fresh and quality foods, but also increased dependency to other areas for food supply. Over the period of 22 years (1990-2012) residential area was highly increased (13.05\%) in comparison to others. The residential area used to cover only $3.02 \%$ (2183 ha.) of the total area in 1990; but it increased to 6.4\% (4618 ha.) in 2000 and to $13.05 \%$ (9419 ha) in 2012. It can be projected that, if system using 
gravels covering $0.5 \mathrm{~m}^{2}$ area is established in the total household $(\mathrm{HH})$ $(607,324), 643,763.440 \mathrm{~kg}$ (643.76 ton) of spinach can be produced in the valley within 40 days from single harvest. The system can work round the year, if optimum temperature is maintained. The production can further be increased, if the uncultivable lands, open space, fallow lands, etc. within the valley are used. Thus, this reflects that the aquaponics can be used as a potential option for urban food supplement in Kathmandu Valley.

\section{CONCLUSION}

In Kathmandu Valley, built-up area has been increasing rapidly resulting in to shrinkage of agricultural land affecting food production system and making valley dwellers vulnerable. The present study shows that aquaponics helps to produce supplement food (fish and vegetables) in the areas where cultivable land and water is limited, as in Kathmandu Valley. This system produces food in soil-less condition without using any chemical fertilizers and pesticides as it uses fish rearing water to grow the vegetables. In this study, growth of Indian spinach more effective in gravel compared to hog-plum seeds. In connection to fish, the results indicate possibility of fish production in aquaponics; however no comparative growth performance could be measured as different fish species were used in different bed media (hog-plum seed and gravel). Thus, for comparative analysis of growth performance of fish in different media, further research is needed. Moreover, the present study has indicated possibility of aquaponics in Kathmandu Valley, further detailed study in small domestic as well as large commercial scale system is urged for evaluating cost-benefit for commercial production of aquaponics system in urban areas of Nepal.

\section{ACKNOWLEDGEMENTS}

The authors express sincere gratitude to the Central Department of Environment Science, Tribhuvan University for providing the necessary support to carry out the work. The authors are also thankful to Mr. Mangal Man Bajracharya for availing his rooftop for experimental set-up. The authors are grateful to the anonymous reviewers for their critical review for bringing the article in the present shape. The authors also sincerely acknowledge Dr. Ramesh Prassad Sapkota for his valuable support in statistical tools and in-depth review of the manuscript. 


\section{REFERENCES}

Abdulkhader, M. (2014). Latest disruptive agri-technology Aquaponics: Grow fish and vegetables - save, space, time and money. Aquaponics, 1-12.

Bekcan, S., Dogankaya, L., \& Cakirogullari, G. C. (2006). Growth and body composition of European catfish (Silurus glanis L.) fed diets containing different percentages of protein. The Israeli Journal of Aquaculture- Bamidgeh, 58(2): 137-142.

Bethe, L. A. (2014). Effect of foliar spray of compost tea on water spinach (Ipomoea aquatica) in Aquaponic System. Bangladesh Agricultural University, Department of Aquaculture, Mymensingh.

Blidariu, F., Radulov, I., Lalescu, D., Drasovean, A., \& Grozea, A. (2013). Evaluation of nitrate level in green lettuce conventional grown under natural conditions and aquaponic system. Animal Science and Biotechnologies, 46(1): 244-250.

Consulting, H. (2013). Aquaponics Research Project: The relevance of Aquaponics to the New Zealand aid programme particularly in the Pacific. Commissioned Report for New Zealand Aid Programme, Ministry of Foreign Affairs and Trade.

Dehaghani, P. G., Baboli, M. J., Moghadam, A. T., \& Pourfarhadi, M. (2015). Effect of symbiotic dietary supplementation on survival, growth performance, and digestive enzyme activities of common carp (Cyprinus carpio) Fingerlings. Czech Journal of Animal Science, 5: 224-232.

Dixit, A., Chettri, M.R., Dixit, K.M., Wenju, R., Aryal, M., Dongol, U., Rai, D.R., Thapa, K., Devkota, M., \& Subedi, Y. (2014). Building urban resilience. Assessing urban and peri-urban agriculture in Kathmandu, Nepal. In: Padgham, J. and Jabbour. J. (eds.). United Nations Environment Programme (UNEP), Nairobi, Kenya.

Goddek, S., Delaide, B., Mankasingh, U., Ragnarsdottir, K.V., Jijakli, H., \& Thorarinsdottir, R. (2015).Challenges of sustainable and commercial aquaponics. Sustainability, 7(4): 4199-4224. 
Goodman, E. R. (2005). Aquaponics: Community and economic development. (Unpublished BA Thesis), Department of Urban Studies and Planning, Massachusetts Institute of Technology, USA.

Himadri, P., \& Debajyoti, C. (2012). Evaluation of growth performance of walking catfish (Clarias batrachus) using low cost fish feed. International Journal of Pharmacy and Biological Science, 2(2): 288-297.

Hossain, N., Islam, M., Alamgir, M., \& Kibria, M. G. (2014). Growth response of Indian spinach to biogas plant residues. IOSR Journal of Pharmacy and Biological Science, 9(2): 1-6.

Hussain, T., Verma, A. K., Tiwari, V. K., Prakash, C., Rathore, G., Shete, A. P., \& Nuwansi, K. K. T. (2014). Optimizing Koi carp, Cyprinus carpio var. Koi (Linnaeus, 1758), stocking density and nutrient recycling with spinach in an aquaponic system. Journal of the World Aquaculture Society, 45(6): 652-661.

KVDA. (2015). Draft: 20 years strategic development master plan (20152035) for Kathmandu Valley. Kathmandu Valley Development Authority, Kathmandu, Nepal.

Lennard, W. (2010). A new look at NFT aquaponic. Aquaponic Journal, 56:16-19.

Nelson, B. R. L. (2008). Aquaponic Equipment the Bio Filter. Aquaponic Journal, 48: 22-23.

Rakocy, J.E., Masser, M.P., \& Losordo, T.M. (2006). Re-circulating aquaculture tank production systems: Aquaponics- integrating fish and plant culture. Southern Regional Aquaculture Center Publication No., 454.

Roy, M., Salam, M. A., Hossain, M. B., \& Shamsuddin, M. (2013). Feasibility study of aquaponics in poly-culture pond. World Applied Sciences Journal, 23(5): 588-592.

Sace, C. F., \& Fitzsimmons, K. M. (2013). Re-circulating aquaponic systems using Nile tilapia (Oreochromis niloticus) and freshwater prawn (Macrobrachium rosenbergii) poly-culture and the productivity of selected leafy vegetables. Merit Research Journals, 1(1): 11-29. 
44 AQUAPONICS: A POTENTIAL OPTION FOR URBAN FOOD ...

Thapa, R. B., \& Murayama, Y. (2009). Examining spatiotemporal urbanization patterns in Kathmandu Valley, Nepal: Remote sensing and spatial metrics approaches. Remote Sensing, 1: 534-556.

Tyson, R. V, Treadwell, D. D., \& Simonne, E. H. (2011). Opportunities and challenges to sustainability in aquaponic systems: A review. Hort Technology, 21(1): 1-6. 